\title{
Innovative Inquiry-based Methods in Learning and Teaching Science
}

\author{
Lilla Bónus (Corresponding author) \\ Doctoral School of Education, University of Szeged, Szeged, Hungary \\ H-6722 Szeged, Petőfi Sgt. 30-34 \\ E-mail: bonus.lilla@edu.u-szeged.hu \\ Erzsébet Antal \\ Biology Methodology Group, Department of Physiology \\ Anatomy and Neuroscience, University of Szeged, Szeged, Hungary \\ H-6726 Szeged, Közép fasor 52. \\ Email: nagylne@bio.u-szeged.hu
}

Received: June 2, 2021

Accepted: July 2, $2021 \quad$ Published: August 1, 2021

doi:10.5296/jse.v11i3.18700

URL: https://doi.org/10.5296/jse.v11i3.18700

\begin{abstract}
The purpose of the study is to synthesize the peer-reviewed literature about innovative inquiry-based approaches for science learning and teaching. This study answers the following research questions: (1) Based on the peer-reviewed literature, what hybrid inquiry-based learning (IBL) approaches exist which respond to the challenges and expectations of education in the 21st century? (2) What features do they have? (3) What empirical evidence supports their effectiveness? (4) At which levels of education do they appear? (5) What learning outcomes are achieved? Using the methodology of systematic literature review, 110 articles obtained by the Google Scholar engine. We selected different approaches based on the following criteria: (1) they respond to the challenges and expectations of education in the 21 st century, (2) technology supports the learning and teaching process, and (3) IBL is combined with some other learning approaches to increase the efficiency of the learning and teaching process. The full texts of 54 studies were read and assessed that satisfied the inclusion criteria. Four categories of hybrid IBL were identified: project-based inquiry learning, game-transformed inquiry-based learning, web-based collaborative inquiry learning, and simulation-based inquiry learning. We define and describe these approaches and present
\end{abstract}




\section{Macrothink

the empirical work in detail. Finally, we compare the presented learning approaches and highlight the limitations of technology integration into the classroom. This study helps to draw attention to the huge pedagogical potential of these technology-supported hybrid IBL approaches and the value of researching them.

Keywords: inquiry, inquiry-based learning, innovative methods, science teaching 


\section{Introduction}

Different disciplines create new knowledge in different ways; therefore they require different learning styles. Students are interested in a field of science which methods, the way knowledge is created, are in line with their learning style. For successful learning, students' individual learning styles must be consistent with the type of disciplinary knowledge (Kolb, 1984). Therefore, learning approaches that support learners in constructing their own knowledge and motivate them to commit to the task are worthwhile.

Natural sciences are experimental sciences; therefore inquiry and learning by inquiry have always been emphasized in teaching/learning students. As early as the 1996 National Science Education Standards, the concept of scientific inquiry (SI) appeared. On the one hand, SI refers to the research work of scientists as they study nature and propose evidence-based explanations on better understanding it. On the other hand, it also refers to the research activities of students, during which they develop their scientific knowledge and understanding of scientific contents (NRC, 1996).

The scientific activity carried out by students follows the process of scientific research conducted by scientists. The five main features of classroom inquiry are as follows (NRC, 2000, p. 25): Learners (1) are engaged by scientifically oriented questions, (2) give priority to evidence, which allows them to develop and evaluate explanations that address scientifically oriented questions, (3) formulate explanations from evidence to address scientifically oriented questions, (4) evaluate their explanations in light of alternative explanations, particularly those reflecting scientific understanding, and (5) communicate and justify their proposed explanations. Inquiry-based learning (IBL) has become widespread based on the recommendations of NRC (2000). IBL is a student- and research-centered active learning method driven by issues or problems. The emphasis is on the research process and on searching for and understanding of knowledge, while the teacher supports the work of students in a facilitator role (Khan \& O’Rourke, 2005).

25 years have passed since IBL was first recommended by NRC. Since then, society has become knowledge-based. In a society where the main value is knowledge, learners need to acquire skills and competencies that enable them to actively contribute to the economic development. This is also supported by the remarkable development of technology (Ananiadou \& Claro, 2009). These changes have certainly led to the continuous development of IBL. Today we see an increasing prevalence of hybrid methods that combine IBL with other learning approaches such as game- or project-based learning (Spires et al., 2012; Srisawasdi \& Panjaburee, 2018; Ulus \& Oner, 2020).

It is well known that student research/IBL has different levels. Depending on the extent to which the educator assists and directs the whole research process, we can distinguish (1) confirmation inquiry, (2) structured inquiry, (3) guided inquiry and (4) open inquiry. During the confirmation inquiry, the educator formulates the research problem, the procedure and the expected results. In this case the aim of the research is to confirm and prove a previously introduced principle while students practice their inquiry skills. In case of structured inquiry, the teacher is less dominant, the research problem and the methods are still given, but 
students have to formulate their own results independently. The results should in all cases be evidence-based explanations (Banchi \& Bell, 2008). In guided inquiry, students discuss the questions and procedures presented by the teacher; they work together on deciding which procedure should be used to achieve the expected result. The role of the teacher is important here as well, as students need to be given guidance to conduct the research and reach a proper outcome (Zion \& Mendelovici, 2012). The most complex level of IBL is open inquiry. In this case teachers only define the framework of the research for the students, and it is up to them which problem they select for studying. They also design the procedures, and then interpret and compare the achieved results with the baseline problem.

In open inquiry, students must continuously make decisions and review the obtained results; therefore this level reflects the work of real researchers the most (Reid \& Yang, 2002). However, there are studies indicating that students prefer guided inquiry to open inquiry (Chatterjee et al., 2009). The reason behind this could be the experience that if learners are completely left alone with the task, they may not be able to start it. Students may be anxious about not knowing what to do (Trautmann et al., 2004). Therefore, it is important to always keep in mind the students' zone of proximal development (Vygotsky, 1978), whether the goal of the learning process being set in an open inquiry is achievable at all. If students are unfamiliar with the key concepts behind the research and their meaning, they will take pot-luck in finding solutions. For novice students, this can take longer, and during this time they learn almost nothing (Clark et al., 2013). Unguided learning can also make students develop misconceptions and gain incomplete or disordered knowledge (Kirschner et al., 2006). When teachers teach students new knowledge and skills, it is much more efficient to provide explicit guidance in the form of exercises and feedback, as opposed to requiring students to discover knowledge themselves based on aspects they have created. If students decide for themselves what and how to learn, they tend to choose the path they already know, which is not challenging for them. This is driven by the feeling of a sure sense of success and induces more modest learning outcomes (Kirschner \& van Merrienboer, 2013).

The emerging hybrid approaches can also be considered as adding research guidance to the learning/teaching process, determining the nature of the task. For example, some hybrid methods guide learners with game elements (Srisawasdi \& Panjaburee, 2018), while other approaches focus on collaboration (Chu, 2009; Chu et al., 2011). They make the otherwise rather abstract research process come to life, tangible. It is important to note that hybrid learning approaches created by combining methods, in many cases, also involve novel technology that supports learning efficiency even more (Srisawasdi, 2018).

The aim of the study is to examine the peer-reviewed litarure in order to identify, characterize, summarize, and compare the innovative IBL approaches with supported technology and other learning/teaching approaches. This study answers the following research questions: (1) Based on the peer-reviewed literature, what hybrid IBL approaches exist which respond to the challenges and expectations of education in the 21 st century? (2) What features do they have? (3) What empirical evidence supports their effectiveness? (4) At which levels of education do they appear? (5) What learning outcomes are achieved? 


\section{Method}

Systematic literature review and the three-step method were used. Systematic review is a literature review method, which means a detailed evaluation and interpretation by reaching a wide variety of research sources related to a particular research question or subject area. The three-step method refers to (1) planning, (2) examining and (3) reporting. The first step consists of the database selection, criteria establishment, and determination of the categories. The further two steps deal with the description and discussion of the review' results (Alper et al., 2021).

Google Scholar engine was used to find academic sources, because it searches a wide range of disciplines and resources: articles, theses, books, abstracts, academic publishers, universities, etc. The search terms were general, to include as many relevant studies as possible. Search terms used were inquiry-based learning, 21st century skills, and technology. Additional articles were identified using a snowballing method (Wohlin, 2014). In all, the search produced 110 articles.

We selected innovative IBL approaches based on three aspects. On the one hand, we were looking for approaches that respond to the challenges and expectations of education in the 21 st century, and thus aim to develop 21 st century skills. 21 st century skills are comprehensive skills that are necessary to be successful in life and at work, such as critical thinking, problem solving, collaboration, information and communication technology (ICT) literacy, creativity and communication (Binkley et al., 2012). In addition, inquiry skills closely related to critical thinking and problem solving are also included (Bao et al., 2009). As for the second aspect, we preferred approaches in which the learning/teaching process was supported by technology. The essence of our third aspect is to combine IBL with other learning approaches to increase the efficiency of the learning/teaching process. Finally, the full texts of 54 studies were read and assessed that satisfied the inclusion criteria.

\section{Results}

Four main categories emerged from the analysis of the literature: project-based inquiry learning, game-transformed inquiry-based learning, web-based collaborative inquiry learning, and simulation-based inquiry learning. We introduce these approaches based on the further analysis of the literature.

\subsection{Project-based inquiry learning}

Project-based learning (PjBL) and inquiry-oriented learning are gaining more and more emphasis in the international trend of educational research and in national educational standard documents (Chu et al., 2017; NRC, 2012; NGSS Lead States, 2013). PjBIL is a more recent approach than IBL, however, PjBIL has also been present in the international literature for at least two decades (Krajcik et al., 1998), and has become popular again (Bopegedera \& Coughenour, 2020; Chu, 2009; Chu et al., 2011). This is probably due to the fact that during the research project, students use a variety of technological tools, multimedia, and various resources (e.g., the Internet) that allow for discovery and acquisition of new knowledge (Spires et al., 2012). 


\section{Ml Macrothink}

Journal of Studies in Education

ISSN 2162-6952

2021, Vol. 11, No. 3

Project-based inquiry learning is a form of situated learning. Situated learning or situated cognition is rooted from the idea that while teaching and preparing students for school, we have to build a bridge to connect the theoretical knowledge acquired in formal education and the application of this knowledge in real life situations, e.g. at a workplace (Resnick, 1987). It assumes that the individual is a member of a community and they are in close interaction during the learning process, while acquiering new skills and competencies that are indispensable in life, in the world of work. It can also be described as a process that takes place through legitimate peripheral participation in professional communities (Lave \& Wenger, 1991). This learning approach is referred to by several names: project-based inquiry learning, inquiry project-based learning. In both cases, IBL is combined with PjBL. PjBIL aims to engage students in a serious, complex intellectual work that motivates them by the challenge of creating new knowledge (Spires et al., 2012). In project-based tasks, students work together as a team to achieve a common goal, which is usually to create a final product. This can be a report, a presentation, or an analysis (Chu et al., 2011; Krajcik et al., 1998; Spires et al., 2012). Collaborative problem solving, which is a feature of project-based learning, does not appear as an independent skill but as part of the formal education's tasks (OECD, 2017). In line with the IBL, the PjBL rests on the constructivist basis that the learner gains a deeper understanding by actively participating in the construction of their own knowledge and by the teacher as a facilitator of learning. Students need to ask scientifically valid questions that they need to answer by gathering the appropriate information (Spires et al., 2012). This, in itself, is true for any constructivist, active learning approach, therefore it is worth considering the following PjBL-specific features (Krajcik \& Blumenfeld, 2006): (1) it is question-driven, which question is aimed to solve a problem, (2) students explore this issue by participating in an autenthic situated inquiry, (3) collaboration, (4) the use of technological tools to support learning.

A common feature of project-based inquiry learning (PjBIL) and problem-based learning (PBL) is that they both focus on solving a relevant, real-world problem. Some researchers also state that PjBIL is derived from PBL (Boss \& Krauss, 2007). Several learning approaches have grown out of PBL, such as project-based learning itself. Another common feature of PjBL and PBL is that they are student-centered, both contain authentic ill-structuted tasks, and they include collaborative learning guided by the teacher or tutor. At the same time, PjBL's student-centeredness is more pronounced compared to PBL, as it relies more on the learner's inputs during the projects (Loyens et al., 2012). Furthermore, in PjBL, the educator appears more in the role of "instructor" and "coach," while in PBL, the educator can best be described as a tutor (Savery, 2006).

It is important to note that altough $\mathrm{PBL}$ and IBL have similar properties there are fundamental differences between them. The difference between IBL and PBL is worth examining from three aspects: (1) the main issue around which learning is organized, (2) the time needed, and (3) the form of work (Spronken-Smith et al., 2007). In PBL, students examine questions that already have the answers, so new discovery is not part of the learning process, unlike it is in case of IBL. For the latter, students often need to perform examinations to determine possible outcomes, so there are not necessarily predefined responses (Khan \& 
O'Rourke, 2005). Thus, the two approaches develop completely different ways of learning. This is why IBL is more time-consuming compared to PBL. There is also a strong emphasis on the mode of collaboraations, as in the case of IBL, the collaboration of students in groups, is optional. However, working in groups is a characteristic feature of PBL (Khan \& O'Rourke, 2005; Spronken-Smith et al., 2007). Furthermore, in case of IBL, the teacher appears in the role of an expert, but it is not characteristic for PBL. In IBL, the educator facilitates the learning process and also provides information as a tutor. In PBL, the tutor only facilitates and does not provide additional information about the problem to be investigated (Savery, 2006).

Therefore, PjBIL is an active learning approach that focuses on some relevant, real-world problems of interest to learners. This is supported by the fact that the research question is formulated by the students themselves and then, in collaboration with each other, working in groups, they create products that answer or are related to the research question. In PjBIL, the emphasis is on research as well as collaboration. This is important because collaboration, as well as inquiry skills related closely to research, can be considered as 21 st century skills (Binkley et al., 2012). The collaborative school culture clearly improves the students' understanding of STEM (Science, Technology, Engineering, Mathematics) (Hesse et al., 2015; Lomos et al., 2011; OECD, 2017). The relationship between PBL, IBL, and PjBIL is shown in Figure 1.

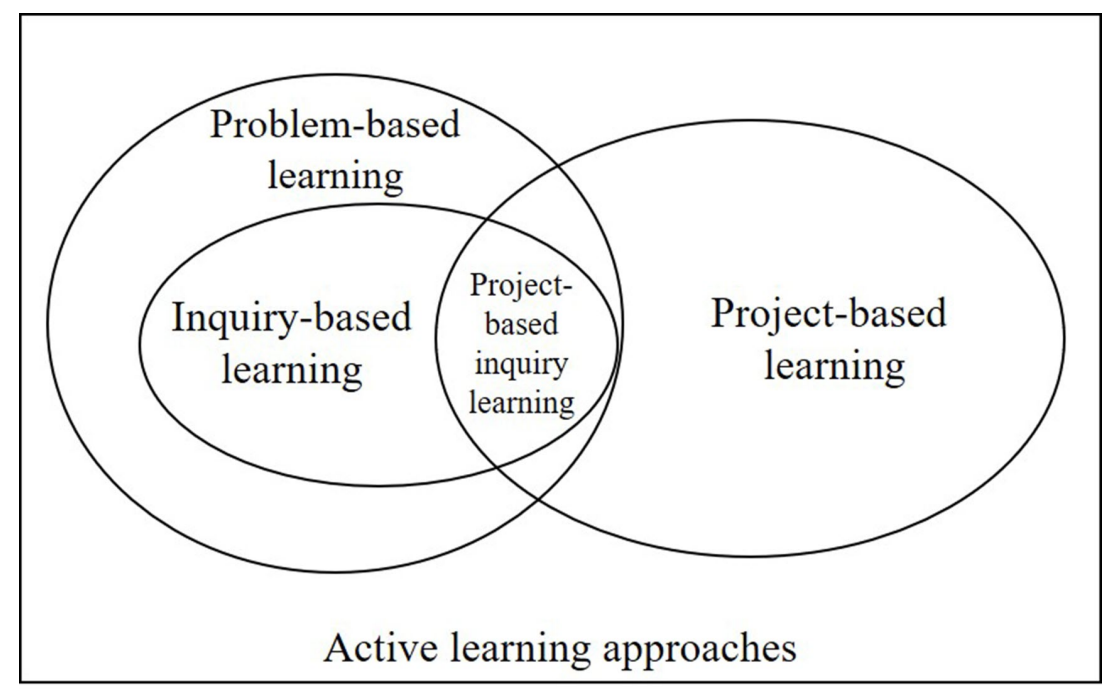

Figure 1. The relationship between problem-based learning, inquiry-based learning, project-based learning and project-based inquiry learning (based on Boss \& Krauss, 2007;

Sproken-Smith et al., 2007; Krajcik \& Blumenfeld, 2006)

Hereunder, we present some studies related to PjBIL and the lessons learnt from them. Krajcik et al. (1998) examined the inquiry skills of 7 th grade students. During the development, students worked in groups and were given various inquiry-related projects. After each project, the composition of the groups was changed, in that way each project was completed by a newly formed group. The researchers found that students carefully designed the experiments and the procedures, thought about control and sample, and how to organize the data collection. At the same time, it was difficult for students to formulate a scientifically 
valid research question, to systematically collect and analyze data, and to draw conclusions.

Elementary school students were also studied in another experiment. Students participated in two PjBIL sessions that had a positive impact on their information literacy and informational technology skills (Chu et al., 2011). Spires et al. (2012) reported an experiment in which high school students made videos with the goal of gaining new disciplinary knowledge. Their research emphasizes that content from $\mathrm{PjBIL}$ can be further developed with multimedia Internet resources. Through Internet access, students can share their findings with a wider and more distant audience while getting feedback and potential inspiration from the work of others. Researchers also make recommendations for practical implementation.

\subsection{Game-transformed inquiry-based learning}

Game-transformed inquiry-based learning is a new area of research in education. The term in this form appeared in the international literature in 2018 (Srisawasdi \& Panjaburee, 2018), however, similar concepts appeared earlier (Table 1).

Table 1. The emergence of term game-trasnformed inquiry-based learning in the international literature

\begin{tabular}{ll}
\hline \multicolumn{1}{c}{ Terms } & \multicolumn{1}{c}{ References } \\
\hline Game-transformed inquiry-based learning & Srisawasdi \& Panjaburee, 2018 \\
\hline Game-based inquiry playing & Dorji et al., 2015 \\
\hline Inquiry in open-ended game-based learning & Sabourin \& Lester, 2014 \\
\hline Game-based open inquiry & Meesuk \& Srisawasdi, 2014 \\
\hline Game-based inquiry learning & Kennedy-Clark et al., 2011 \\
\hline
\end{tabular}

The term game-transformed inquiry-based learning refers to the cross section of digital game-based learning (DGBL) and inquiry-based learning when IBL takes place in a digital game environment (Srisawasdi \& Panjaburee, 2018). Therefore, this new idea carries the benefits of both concepts. Educational games tend to emphasize the fantasy world, challenge, entertainment and reward (Prensky, 2001; Sabourin \& Lester, 2014). In addition, it is important to create a balance between pedagogical content and game elements in educational digital games (Rooney, 2012). Furthermore, digital games must rely on solid pedagogical principles and scenarios that provide learning activities (Dorji et al., 2015). The emphasis is on transforming the scientific content into game strategies and the pedagogical use of playing, with the aim of improving students' learning performance. This need has created the game-transformed inquiry-based learning concept, which is a process-oriented, inquiry-based active learning approach (Srisawasdi \& Panjaburee, 2018).

The learning environment offered by DGBL can provide an extra motivation that supports the successful completion of the research (Ketelhut et al., 2010). The digital environment ensures access to the research techniques and settles safe management and conduct of a wide range of activities. An important feature is that it provides opportunities for practice, repetition and it also eliminates the practical limitations of the learning context (Srisawasdi \& Panjaburee, 


\section{$\Lambda$ Macrothink}

2018). According to Bressler and Bodzin (2016), digital games for educational purposes promote the flow experience and support the development of science practices as well. Furthermore, they also have a positive effect on motivation and attitude towards the subject (Hwang \& Chen, 2017; Kennedy-Clark et al., 2011; Srisawasdi \& Panjaburee, 2018).

When designing digital games for educational purposes, multimodality, tasks, and feedback are extremely emphasized. Multimodality provides interaction between the game and the learner through multimedia elements, interface, and narrative. Tasks should be designed at different levels in order to help learners adapt to the play environment (Tan et al., 2007). Another important element is the preparation of the narrative. A good narrative, i.e. a frame story, helps learners to immerse themselves in the game, provides a dynamic interaction between the player and the story, cognition and knowledge, action and understanding, it takes them into a new place in both space and time, into the world of play, while it also engages the player emotionally (Barab et al., 2010).

There is a strong interest in the international literature about the digital educational games that, when embedded in content, achieve success in terms of student learning outcomes. Examples include Crystal Island, River city and Factory. Crystal Island is a biology-themed, narrative- and learner-centered virtual adventure game for 8th-graders. The central mystery is what made the inhabitants of the island sick. Students must be solved the mystery by applying the inquiry skills. Students' knowledge of the topic, their commitment to the task increased, and a positive correlation was shown between commitment, student feelings, and strategies that are key features of research and problem solving (Lester et al., 2014; Sabourin \& Lester, 2014).

River city is a biology-themed virtual learning environment for high school students. Students work in small groups, collect data, formulate hypotheses, and then test them. Finally, they write an authentic laboratory report and compare their research with the work of other classes. River city increased students' interest in having a career in the field of natural sciences and their knowledge of content (Ketelhut et al., 2010). Factory game is a chemistry-themed virtual learning environment, which contributes to the increasing motivation of high school students and promotes an understanding of different chemical concepts (Srisawasdi \& Panjaburee, 2018).

\subsection{Web-based collaborative inquiry learning}

The term web-based collaborative inquiry learning (WCIL) was introduced into the international literature by Chang, Sung and Lee (2003). It refers to a student-centered activity in which students use the Internet as a source of information and students collaborate with each other in each phase of inquiry. The term also occurs as computer-supported collaborative inquiry learning (Kollar et al., 2007; Mäkitalo-Siegl et al., 2010; Uribe et al., 2020).

The approach aims to increase students' motivation, arouse their interest in the natural sciences, and provide students with knowledge about how science works, such as how to carry out a scientific research step by step (Bell et al., 2010). The term Nature of Science (NOS) refers to the epistemology of science, science as a mode of cognition, or the values 
and beliefs associated with scientific knowledge and the development of scientific knowledge (Abd-El-Khalick \& Lederman, 2000). Therefore, the legitimacy of the approach is justified by the growing demand for inquiry-oriented practices (NRC, 2012; NGSS Lead States, 2013) and the rise of computer-supported collaborative learning (Bell et al., 2010).

Chang et al. (2003) proposed 4 phases of WCIL. These are (1) anchoring and planning, (2) individual inquiry, (3) collaborative inquiry, and (4) concluding group's results (Figure 2).

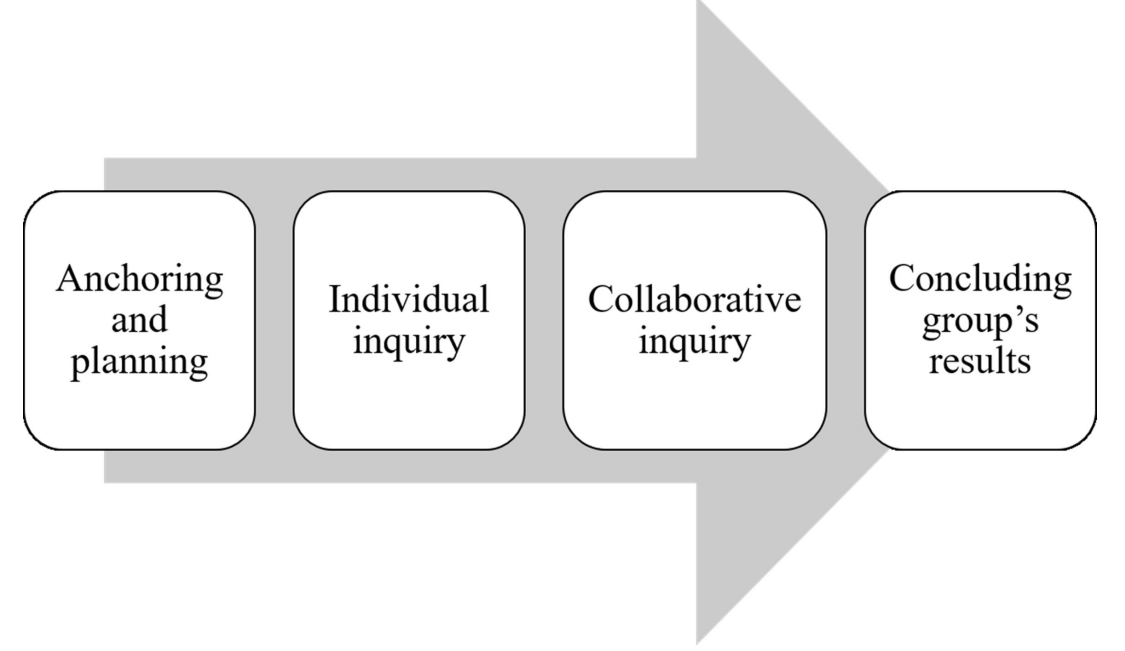

Figure 2. The phases of web-based collaborative inquiry learning (based on Chang et al., 2003)

Within each phase, additional learning activities and learning objectives are defined; the latter aimed at practicing some inquiry or collaborative skills. Students complete the first two phases independently, during which the problem to be investigated is identified, the hypothesis is formulated, and relevant information is collected on the Internet to support the hypothesis or to reformulate it based on the new information. The third, collaborative phase is characterized by online information sharing, presentation and discussion of hypotheses, and interaction between peers. This is when the most important element of the WCIL, the collaborative argumentation, takes place, during which the students have the opportunity to discuss what information and evidence support the hypothesis. At the same time, they are also enriched with domain-specific knowledge during the discussion (Kollar et al., 2007). In the last phase, the group product is prepared and finalized (Chang et al., 2003).

This approach also responds to the idea that in the 21 st century, the teacher is no longer the only source of knowledge and the learner has the ability to control computer systems, programs, and collect data. Therefore, technology is an important tool in WCIL, as it allows programs to perform simple tasks (e.g., display, organize, and calculate data) instead of learners (Bell et al., 2010). The teacher's activity therefore changes here, just like in IBL, and can be summarized in five principles: (1) envision the lesson, (2) enable collaboration, (3) encourage students, (4) ensure learning, and (5) evaluate achievement (Urhahne et al., 2010).

The World Wide Web used as a resource in inquiry learning supports the development of higher-order thinking skills (e.g., critical thinking, problem solving) (Linn et al., 2003). At the same time, some researchers point out that students have difficulty at self-regulating learning 
and this type of purposeful use of the Internet, as it provides an opportunity for the learner to deal with something else. Therefore, proper scaffolding is extremely important to help the learner in the learning process. Raes et al. (2012) compared the effects of two types of scaffolding on knowledge acquisition and support for information problem solving: technology-enhanced scaffolding and teacher-enhanced scaffolding. The essence of technology-enhanced scaffolding is that part of the learning process is displayed on a screen, and learners have some procedural knowledge on how to complete the task they see on the screen, but this will not happen spontaneously. Therefore, questions and instructions should be placed in the task, which encourage the learner to activate cognitive processes. In the case of teacher-enhanced scaffolding, instructions are given by the teacher, and are determined by the current needs of the students, meanwhile technology-enhanced scaffolding is static (Bannert, 2009; Raes et al., 2012). Both scaffoldings have been shown to be efficient in knowledge acquisition and metacognitive awareness of information problem solving (Raes et al., 2012).

A kind of scaffolding is also provided by the web-based inquiry science environment (WISE), which has features that support learning and emphasize the process of knowledge integration. Knowledge integration (KI) treats ideas as building blocks and mobilizes the processes by which building blocks can be produced. It aims to promote a coherent understanding of research and science in education by emphasizing the ability to connect ideas, differentiate between ideas, and construct arguments based on guiding ideas. WISE has the potential to increase the knowledge integration of high school students (Ulus \& Oner, 2020). Involve students in research activities by aiming to examine issues that are relevant to students. It also has several features, such as the Idea Basket or the Explanation Builder, that support students in creating different ideas, tracking them, and suggesting explanations based on the ideas (Clark \& Linn, 2013).

\subsection{Simulation-based inquiry learning}

Simulation-based inquiry learning is a teaching/learning approach that involves students in the process of scientific inquiry using computer simulations (Lazonder et al., 2010; Mulder et al., 2015). So, the term means incorporating simulations into IBL, it is a kind of guided inquiry learning. Formal research on simulation-based learning (SBL) began in the 1960s, and the approach further evolved since the 1980s by the invention of new technologies. Computer-based simulations and games have emerged that evolved into online web-based simulations by the 2000s. Currently, its most researched areas are the use of multimedia and game-based learning in SBL, as well as teaching sustainability with SBL (Hallinger \& Wang, 2019).

Computer simulations are computer programs. Programs are based on a model that is usually a simplification of a real natural phenomenon. The use of simulations is reasonable since it may be difficult or impossible to model the real world with its every detail. Sometimes a simulation is enough to achieve our goal, and it should also be kept in mind that using a more realistic model always means higher costs (de Jong, 2011). Thus, simulations are computer-generated, dynamic models of the real world and its processes (Smetana \& Bell, 


\section{MlMacrothink}

Journal of Studies in Education

ISSN 2162-6952

2021, Vol. 11, No. 3

2012). The main advantages of such a learning environment are that simulation arouses curiosity in learners through open inquiry; provides a basic theoretical background for developing testable hypotheses; provides an opportunity for the learner to create and observe experimental settings; and helps learners draw vidence-based conclusions (Srisawasdi, 2018). It has the additional advantage that the student's scientific thinking and content knowledge can also be developed by interacting with the simulation (Lazonder et al., 2010). Furthermore, guided inquiry learning can support students at different levels of science achievement to hihgly engage in science inquiry (Wen et al., 2020).

A number of useful information can be obtained from the learner-simulation interaction. On the one hand, it can be examined directly whether the learner is able to set up a simulation, design a new setting to test a hypothesis, or can draw the appropriate conclusions using the simulation. On the other hand, it is worth logging student activity. During logging, the program stores events that represent student actions. This provides an opportunity for later logfile analysis, which is a new trend in educational research. Based on the logged events, it is possible to examine whether the sequence of events generated by the students fits to a theoretical schema, to analyze the time spent on the task (time-on-task) and, in general, the behavior of the students in the program (Alrababah \& Molnár, 2021).

Several studies deal with the fact that in simulation-based inquiry learning, as well as in the case of web-based collaborative inquiry, scaffolding and the existence of background knowledge are very important (Gijlers \& de Jong, 2013; Huang et al., 2016; Kukkonen et al., 2013). Kukkonen et al. (2013) examined on a group of 5th grade students how the concepts used in a simulation changed in the students' representation. In the experiment, the researchers found that simulation-based inquiry learning enriched students' greenhouse gas concepts compared to students who did not participate in the sessions.

According to Smetana and Bell (2012), computer simulations are most efficient in education when (1) they are used as a supplement; (2) include high quality support structures; (3) encourage student reflection; (4) promote cognitive dissonance. If these aspects are adhered to, simulations can be used to develop students' knowledge of science content and inquiry skills, as well as to facilitate conceptual change. In a study by Srisawasdi and Panjaburee (2015), summarizing the work of several authors, they show that simulation-based inquiry learning causes changes in students' alternative ideas, improves the performance of acquiring intuitive domain-specific knowledge, but at the same time highlights that it results in better quality knowledge than formalized theoretical-focused knowledge, helps to understand concepts coherently, and promotes a positive judgement of science. All of the above are important aims in teaching science subjects (NGGS Lead States, 2013).

\section{Discussion}

To compare the innovative inquiry-based learning approaches presented in this study, Table 2 was prepared. The following aspects were considered relevant for the comparison: (1) main focus, (2) students' role, (3) teachers' role, (4) additional focus compared to IBL, (5) learning outcomes, and (6) educational level. 


\section{Macrothink}

Summarizing the innovative inquiry-based learning approaches presented, we can state that in each case, learning takes place through scientific inquiry. Thus, the emphasis is that by participating in a research, the learner can learn a number of skills and abilities (Kuang, Eysinck, \& de Jong, 2020), as well as enrich subject knowledge (Srisawasdi \& Panjaburee, 2018). Furthermore, they are organized around active learning methods that rest on constructivist foundations, so they emphasize the active participation of learners in constructing their knowledge. As a result, the role of teachers also changes, helping the process as a facilitator. In addition, they use a rich set of technological tools to respond well to the challenges and expectations of the 21 st century. It is common among research on approaches that the works of the last 2-3 decades are the most relevant and there is little empirical evidence.

The presented approaches differ in the phases of learning, the forms of work, the technologies used and to what they focus beside the main research of IBL. The learning objectives and learning outcomes are very diverse for each approach, and they show little development in inquiry skills, which is otherwise an important goal of the original IBL concept. Among the approaches, the application of project-based inquiry learning, game-transformed inquiry-based learning and simulation-based inquiry learning is present in primary and secondary schools (Chu et al., 2011; Kuang et al., 2020; Lester et al., 2014; Spires et al., 2012; Srisawasdi \& Panjaburee, 2018; Wen et al., 2020), as well as in higher education (Bopegedera \& Coughenour, 2020; Kennedy-Clarke et al., 2011; Bell \& Trundle, 2008), while web-based collaborative inquiry learning typically occurs in secondary schools (Raes et al., 2012) and higher education (Xu \& Xu, 2011). 
Table 2. Comparative table of project-based inquiry learning, game-transformed inquiry-based learning, web-based collaborative inquiry learning and simulation-based inquiry learning

\begin{tabular}{|c|c|c|c|c|}
\hline $\begin{array}{l}\text { Comparative } \\
\text { aspects }\end{array}$ & $\begin{array}{c}\text { Project-based } \\
\text { inquiry learning }\end{array}$ & $\begin{array}{l}\text { Game-transformed } \\
\text { inquiry-based learning }\end{array}$ & $\begin{array}{l}\text { Web-based } \\
\text { collaborative } \\
\text { inquiry learning }\end{array}$ & $\begin{array}{l}\text { Simulation-based } \\
\text { inquiry learning }\end{array}$ \\
\hline Main focus & \multicolumn{4}{|c|}{ Learning through inquiry } \\
\hline Students' role & \multicolumn{4}{|c|}{ Actively participates in the construction of his/her knowledge } \\
\hline Teachers' role & \multicolumn{4}{|c|}{ Facilitator } \\
\hline $\begin{array}{l}\text { Additional } \\
\text { focus } \\
\text { compared to } \\
\text { IBL }\end{array}$ & $\begin{array}{c}\text { Collaborative team } \\
\text { work }\end{array}$ & High engangement in task & $\begin{array}{l}\text { Web-based } \\
\text { collaborative } \\
\text { team work }\end{array}$ & $\begin{array}{l}\text { Real-world } \\
\text { phenomena }\end{array}$ \\
\hline $\begin{array}{l}\text { Learning } \\
\text { outcomes }\end{array}$ & $\begin{array}{c}\text { Information } \\
\text { literacy and } \\
\text { information skills } \\
\text { (Chu et al., 2011) } \\
\text { Content knowledge } \\
\text { (Bopegedera \& } \\
\text { Coughenour, 2020; } \\
\text { Spires et al., 2012) }\end{array}$ & $\begin{array}{c}\text { Content knowledge, } \\
\text { problem solving (Lester et } \\
\text { al., 2014) } \\
\text { Content knowledge, } \\
\text { motivation (Srisawasdi \& } \\
\text { Panjaburee, 2018) } \\
\text { Positive change in attitudes } \\
\text { towards game-based } \\
\text { learning in science } \\
\text { education (Kennedy-Clarke } \\
\text { et al., 2011) } \\
\text { Intrinzic motivation, } \\
\text { students' perceptions of } \\
\text { their problem solving and } \\
\text { critical thinking (Hwang \& } \\
\text { Chen, 2017) }\end{array}$ & $\begin{array}{c}\text { Digital literacy } \\
\text { (Raes et al., } \\
2012) \\
\text { Information } \\
\text { literacy } \\
(\mathrm{Xu} \& \mathrm{Xu}, \\
2011)\end{array}$ & $\begin{array}{c}\text { Scientific literacy } \\
\text { (Wen et al., 2020) } \\
\text { Hypothesis } \\
\text { generation, } \\
\text { data collection, } \\
\text { domain knowledge } \\
\text { (Kuang et al., 2020) } \\
\text { Scientific } \\
\text { understanding } \\
\text { (Bell \& Trundle, } \\
\text { 2008) } \\
\text { Science epistemic } \\
\text { beliefs (Huang et al., } \\
\text { 2016) }\end{array}$ \\
\hline $\begin{array}{c}\text { Educational } \\
\text { level }\end{array}$ & $\begin{array}{c}\text { Primary school } \\
\text { (Chu et al., 2011) } \\
\text { Secondary school } \\
\text { (Spires et al., 2012) } \\
\text { Higher education } \\
\text { (Bopegedera \& } \\
\text { Coughenour, 2020) }\end{array}$ & $\begin{array}{c}\text { Primary school (Hwang \& } \\
\text { Chen, 2017; Lester et al., } \\
\text { 2014) } \\
\text { Secondary school } \\
\text { (Srisawasdi \& Panjaburee, } \\
\text { 2018) } \\
\text { Higher education } \\
\text { (Kennedy-Clarke et al., } \\
\text { 2011) }\end{array}$ & $\begin{array}{c}\text { Secondary } \\
\text { school (Raes et } \\
\text { al., 2012) } \\
\text { Higher } \\
\text { education (Xu } \\
\& \mathrm{Xu}, 2011)\end{array}$ & $\begin{array}{l}\text { Primary school } \\
\text { (Huang et al., 2016; } \\
\text { Wen et al., 2020) } \\
\text { Secondary school } \\
\text { (Kuang et al., 2020) } \\
\text { Higher education } \\
\text { (Bell \& Trundle, } \\
\text { 2008) }\end{array}$ \\
\hline
\end{tabular}




\section{Limitation}

One of the limitations of the study is that the articles reviewed were quested by the Google Scholar engine, and we did not use the big databases directly. Another limitation is that we did not consider the specific journals regarding different fields of science.

\section{Conclusion}

The most important outcomes of science teaching are content knowledge, scientific inquiry skills, interest, and motivation. IBL and other methods combined with IBL and technology were proved to facilitate the process of achieving the mentioned outcomes. Technology can be used in many ways to support science education and it can be applied to almost every step of IBL. Technology can also be used as guidance, scaffold, adaptive system, reflective support, and so on (de Jong, 2019; Pedaste et al., 2017). Therefore, technology becomes an integral part of learning and teaching, and a significant issue for teachers as well, from the beginning of preparing learning experiences through to the teaching and learning process (Eady \& Lockyer, 2013).

However, there are some difficulties in successfully integrating technology into lessons. Therefore, it is necessary to discuss the factors that hinder the integration of technology in lessons. These factors are classified into two groups by Ertmer (1999). First-order barriers are extrinsic factors for teachers that are related to resource types (e.g., equipment, time, and training) and that are either incomplete or inadequately provided. Fundamental changes are mostly hampered by second-order barriers, as these problems cannot be solved by providing resources. Secondary constraints are related to teachers' beliefs about teaching and learning (e.g., teachers' pedagogical beliefs). These barriers may be present together, but whichever barrier appears, it hinders the effective integration of technology into teaching.

According to Tsai and Chai (2012), an additional third-order barrier is also present during the integration of technology into a lesson. To overcome this limitation, the term "design thinking" is proposed, which is a combination of knowledge and practice at a level in which the advancement of ICT is associated with pedagogical benefits. It interprets and treats firstand second-order barriers as problems that can be solved through creative thinking.

Successful integration of technology into the classroom requires different kinds of knowledge and depends on the teachers' beliefs, confidence, and motivation. Therefore, if we want technology-based learning approaches to become widespread in public education, the above-mentioned barriers must also be considered (Hsu et al., 2017).

\section{References}

Abd-El-Khalick, F., \& Lederman, N. G. (2000). Improving science teachers' conceptions of the nature of science: A critical review of the literature. International Journal of Science Education, 22(7), 665-701. https://doi.org/10.1080/09500690050044044

Alper, A., Oztaş, E. S., Atun, H., Cinar, D., \& Moyenga, M. (2021). A systematic literature review towards the research of game-based learning with augmented reality. International Journal of Technology in Education and Science (IJTES), 5(2), 224-244. https://doi.org/10.46328/ijtes.176 
Alrababah, S., \& Molnár, Gy. (2021). Analyzing contextual data in educational context: educational data mining and logfile analysis. Journal of Critical Reviews, 8(1), 261-273. https://doi.org/10.31838/jcr.08.01.31

Ananiadou, K., \& Claro, M. (2009). 21st Century Skills and Competences for New Millennium Learners in OECD Countries, OECD Education Working Papers, No. 41, OECD Publishing. https://doi.org/10.1787/218525261154

Banchi, H., \& Bell, R. (2008). The many levels of inquiry. Science and Children, 46(2), 26-29.

Bannert, M. (2009). Promoting self-regulated learning through prompts. Zeitschrift Fur Padagogische Psychologie, 23(2), 139-145. https://doi.org/10.1024/1010-0652.23.2.139

Bao, L., Cai, T., Koenig, K., Fang, K., Han, J., Wang, J., Liu, Q., Ding, L., Cui, L., Luo, Y., Wang, Y., Li, L., \& Wu, N. (2009). Learning and Scientific Reasoning. Science; 323(5914), 586-587. https://doi.org/10.1126/science. 1167740

Barab, S. A., Gresalfi, M., \& Ingram-Goble, A. (2010). Transformational play: using games to position person, content, and context. Educational Researcher, 39(7), 525-536. https://doi.org/10.3102/0013189X10386593

Bell, R. L., \& Trundle, K. C. (2008). The Use of a Computer Simulation to Promote Scientific Conceptions of Moon Phases. Journal of Research in Science Teaching, 45(3), 346-372. https://doi.org/10.1002/tea.20227

Bell, T., Urhahne, D., Schanze, S., \& Ploetzner, R. (2010). Collaborative Inquiry Learning: Models, tools, and challenges. International Journal of Science Education, 32(3), 349-377. https://doi.org/10.1080/09500690802582241

Binkley, M., Erstad, O., Herman, J., Raizen, S., Ripley M., \& Rumble, M. (2012). Defining Twenty-First Century Skills. In P. Griffin \& E. Care (Eds.), Assessment and Teaching of 21st Century Skills (pp. 17-66). Springer. https://doi.org/10.1007/978-94-007-2324-5_2

Bopegedera, A. M. R. P., \& Coughenour, C. L. (2020). An Interdisciplinary, Project-Based Inquiry into the Chemistry and Geology of Alkaline Surface Lake Waters in the General Chemistry Laboratory. Journal of Chemical Education, 98(4), 1352-1360. https://doi.org/10.1021/acs.jchemed.0c00315

Boss, S., \& Krauss, J. (2007). Reinventing project-based learning: Your field guide to real-world projects in the digital age. International Society for Technology in Education.

Bressler, M. D., \& Bodzin, A. M. (2016). Investigating Flow Experience and Scientific Practices During a Mobile Serious Educational Game. Journal of Science Education and Technology, 25(5), 795-805. https://doi.org/10.1007/s10956-016-9639-z

Chang, K-E., Sung, Y-T., \& Lee, C-L. (2003). Web-based collaborative inquiry learning. Journal of Computer Assisted Learning, 19, 56-69. https://doi.org/10.1046/j.0266-4909.2003.00006.x 


\section{$\Lambda$ Macrothink}

Journal of Studies in Education

ISSN 2162-6952

2021, Vol. 11, No. 3

Chatterjee, S., Williamson, V. M., McCann, K., \& Peck, M. L. (2009). Surveying Students' Attitudes and Perceptions toward Guided-Inquiry and Open-Inquiry Laboratories. Journal of Chemical Education, 86(12), 1427-1432. https://doi.org/10.1021/ed086p1427

Chu, K. W. S. (2009). Inquiry Project-Based Learning with a Partnership of Three Types of Teachers and the School Librarian. Journal of American Society for Information Science and Technology, 60(8), 1671-1686. https://doi.org/10.1002/asi.21084

Chu, K. W. S., Tse, S. K., \& Chow, K. (2011). Using collaborative teaching and inquiry project-based learning to help primary school students develop information literacy and information skills. Library \& Information Science Research, 33, 132-143. https://doi.org/10.1016/j.lisr.2010.07.017

Chu, S. K. W., Reynolds, R. B., Tavares, N. J., Notari, M., \& Lee, V. W. Y. (2017). 21st Century Skills Development through Inquiry-Based Learning from Theory to Practice. Springer Nature Singapore Pte Ltd. https://doi.org/10.1007/978-981-10-2481-8

Clark, D. B., \& Linn, M. C. (2013). The knowledge integration perspective: connections across research and education. In S. Vosniadou (Ed), International handbook of research on conceptual change (pp. 520-538). Routledge.

Clark, R. E., Kirschner, P. A., \& Sweller, J. (2013). Putting students on the path to learning: The case for fully guided instruction. American Educator, 36(1), 6-11.

de Jong, T. (2011). Instruction Based on Computer Simulations. In R. E. Mayer \& P. A. Alexander (Eds.), Handbook of Research on Learning and Instruction (pp. 446-466). Routledge.

de Jong, T. (2019). Moving towards engaged learning in STEM domains; there is no simple answer, but clearly a road ahead. Journal of Computer Assisted Learning, 35(2), 153-167. https://doi.org/10.1111/jcal.12337

Dorji, U., Panjaburee, P., \& Srisawasdi, N. (2015). A learning cycle approach to developing educational computer game for improving students' learning and awareness in electric energy consumption and conservation. Educational Technology \& Society, 18(1), 91-105.

Eady, M. J., \& Lockyer, L. (2013). Tools for learning: technology and teaching strategies: Learning to teach in the primary school. Queensland University of Technology.

Ertmer, P. A. (1999). Addressing first- and second-order barriers to change: strategies for technology integration. Educational Technology Research and Development, 47(4), 47-61. https://doi.org/10.1007/BF02299597

Gijlers, H., \& de Jong, T. (2013). Using Concept Maps to Facilitate Collaborative Simulation-Based Inquiry Learning. Journal of the Learning Sciences, 22(3), 340-374. https://doi.org/10.1080/10508406.2012.748664

Hallinger, P., \& Wang, R. (2019). The Evolution of Simulation-Based Learning Across the Disciplines, 1965-2018: A Science Map of the Literature. Simulation \& Gaming, 51(1), 9-32. 
https://doi.org/10.1177/1046878119888246

Hesse, F., Care, E., Buder, J., Sassenberg, K., \& Griffin, P. (2015). A framework for teachable collaborative problem solving skills. In P. Griffin, B. McGaw \& E. Care (Eds.), Assessment and teaching of 21 st century skills (pp. 37-56). Springer. https://doi.org/10.1007/978-94-017-9395-7_2

Hsu, C-Y., Tsai, M-J., Chang, Y-H., \& Liang, J-C. (2017). Surveying In-Service Teachers' Beliefs about Game-Based Learning and Perceptions of Technological Pedagogical and Content Knowledge of Games. Educational Technology \& Society, 20(1), 134-143.

Huang, K., Ge, X., \& Eseryel, D. (2016). Metaconceptually-enhanced simulation-based inquiry: effects on eighth grade students' conceptual change and science epistemic beliefs. Educational Technology Research and Development, 65(1), 75-100. https://doi.org/10.1007/s11423-016-9462-5

Hwang, G-J., \& Chen, C-H. (2017). Influences of an inquiry-based ubiquitous gaming design on students' learning achievements, motivation, behavioral patterns, and tendency towards critical thinking and problem solving. British Journal of Educational Technology, 48(4), 950-971. https://doi.org/10.1111/bjet.12464

Kennedy-Clark, S., Galstaun, V., \& Anderson, K. (2011). Death in Rome: Using an online game for inquiry-based learning in a pre-service teacher training course. In Y. Baek \& N. Whitton (Eds.), Cases on Digital Game-Based Learning: Methods, Models, and Strategies (pp. 364-382). IGI Global. https://doi.org/10.4018/978-1-4666-2848-9.ch018

Ketelhut, D., Nelson, B., Clarke, J., \& Dede, C. (2010). A Multi-user virtual environment for building higher order inquiry skills in science. British Journal of Educational Technology, 4l(1), 56-68. https://doi.org/10.1111/j.1467-8535.2009.01036.x

Khan, P., \& O’Rourke, K. (2005). Understanding enquiry-based learning. In T. Barrett, I. Maclabhrainn \& H. Fallon (Eds), Handbook of enquiry and problem based learning (pp. 1-12). Centre for Excellence in Learning and Teaching.

Kirschner, P. A., \& van Merriënboer, J. J. (2013). Do learners really know best? Urban legends in education. Educational Psychologist, 48(3), 169-183. https://doi.org/10.1080/00461520.2013.804395

Kirschner, P. A., Sweller, J., \& Clark, R. E. (2006). Why Minimal Guidance During Instruction Does Not Work: An Analysis of the Failure of Constructivist, Discovery, Problem-Based, Experiential, and Inquiry-Based Teaching. Educational Psychologist, 41(2), 75-86. https://doi.org/10.1207/s15326985ep4102_1

Kolb, D. A. (1984). Experiential learning: experience as a source of learning and development. Prentice Hall.

Kollar, I., Fischer, F., \& Slotta, J. D. (2007). Internal and external scripts in computer-supported collaborative inquiry learning. Learning and Instruction, 17(6), 708-721. https://doi.org/10.1016/j.learninstruc.2007.09.021 
Krajcik, J., Blumenfeld, P. C. (2006). Project-based learning. In R. K. Sawyer (Ed.), Project-based Learning (pp. 317-334). Washington University, University Press. https://doi.org/10.1017/CBO9780511816833.020

Krajcik, J., Blumenfeld, P. C., Marx, R. W., Bass, K. M., Fredricks, J., \& Soloway, E. (1998). Inquiry in Project-Based Science Classrooms: Initial Attempts by Middle School Students. Journal of the Learning Sciences, 7(3-4), 313-350. https://doi.org/10.1080/10508406.1998.9672057

Kuang, X., Eysinck, T. H. S., \& de Jong, T. (2020). Effects of providing partial hypotheses as a support for simulation-based inquiry learning. Journal of Computer Assisted Learning, 36(4), 1-15. https://doi.org/10.1111/jcal.12415

Kukkonen, J. E., Kärkkäinen, S., Dillon, P., \& Keinonen, T. (2013). The Effects of Scaffolded Simulation-Based Inquiry Learning on Fifth-Graders' Representations of the Greenhouse Effect. International Journal of Science Education, 36(3), 406-424, http://dx.doi.org/10.1080/09500693.2013.782452

Lave, J., \& Wenger, E. (1991). Situated learning: Legitimate peripheral participation. Cambridge University Press.

Lazonder, A. W., Hagemans, M. G., \& de Jong, T. (2010). Offering and discovering domain information in simulation-based inquiry learning. Learning and Instruction, 20, 511-520. https://doi.org/10.1016/j.learninstruc.2009.08.001

Lester, J. C., Spires, H. A., Nietfeld, J. L., Minogue, J., Mott, B. W., \& Lobene, E. V. (2014). Designing game-based learning environments for elementary science education: A narrative-centered learning perspective. Information Sciences, 264, 4-18. https://doi.org/10.1016/j.ins.2013.09.005

Linn, M. C., Clark, D., \& Slotta, J. D. (2003). WISE design for knowledge integration. Science Education, 87(4), 517-538. https://doi.org/10.1002/sce.10086

Lomos, C., Hofman, R. H., \& Bosker, R. J. (2011). The relationship between departments as professional learning communities and student achievement in secondary schools. Teaching and Teacher Education, 27(4), 722-731. https://doi.org/10.1016/j.tate.2010.12.003

Loyens, S. M. M., Kirschner, P., \& Paas, F. (2012). Problem-based Learning. In K. R. Harris, S. Graham \& T. Urdan (Eds.), APA Educational Psychology Handbook: Vol 3. Application to learning and teaching (pp. 403-425). American Psychological Association. https://doi.org/10.1037/13275-016

Mäkitalo-Siegl, K., Kohlne, C., \& Fischer, F. (2010). Computer-supported collaborative inquiry learning and classroom scripts: Effects on help-seeking processes and learning outcomes. Learning and Instruction, 21, 257-266. https://doi.org/10.1016/j.learninstruc.2010.07.001

Meesuk, K., \& Srisawasdi, N. (2014). Implementation of Student-associated Game-based Open Inquiry in Chemistry Education: Results on Students' Perception and Motivation. In L. 
C.-C., H. Ogata, S. C. Kong \& A. Kashihara (Eds.), Proceedings of the 22nd International Conference on Computers in Education (pp. 219-226). Asia-Pacific Society for Computers in Education.

Mulder, G. Y., Lazonder, A. W., \& de Jong, T. (2015). Simulation-Based Inquiry Learning and Computer Modeling: Pitfalls and Potentials. Simulations \& Gaming, 46(3-4), 322-347. https://doi.org/10.1177/1046878115577159

National Research Council (NRC) (1996). National Science Education Standards. National Academy Press. https://doi.org/10.17226/4962

National Research Council (NRC) (2000). Inquiry and the National Science Education Standards: A guide for teaching and learning. National Academy Press. https://doi.org/10.17226/9596

National Research Council (NRC) (2012). A Framework for K-12 science education: Practices, Crosscutting Concepts, and Core Ideas. The National Academies Press. https://doi.org/10.17226/13165

NGSS Lead States. (2013). Next generation science standards: For states, by states. National Academies Press. https://doi.org/10.17226/18290

OECD (2017). PISA 2015 Assessment and Analytical Framework: Science, Reading, Mathematic, Financial Literacy and Collaborative Problem Solving, revised edition. PISA, OECD Publishing. https://doi.org/10.1787/9789264281820-8-en

Pedaste, M., Leijen, Ä., Saks, K., de Jong, T., \& Gillet, D. (2017). How to link pedagogy, technology and STEM learning? In Y. Hayashi, T. Supnithi, M. Mathews, S. L. Wong, A. F. Mohd Ayub, A. Mitrovic, W. Chen \& J-C. Yang (Eds.), ICCE 2017 - 25th International Conference on Computers in Education: Technology and Innovation: Computer-Based Educational Systems for the 21st Century, Workshop Proceedings (pp. 578-586). Asia-Pacific Society for Computers in Education.

Prensky, M. (2001). Fun, Play and Games: What Makes Games Engaging. McGraw-Hill.

Raes, A., Schellens, T., Wever, D. B., \& Vanderhoven, E. (2012). Scaffolding information problem solving in web-based collaborative inquiry learning. Computers \& Education, 59, 82-94. https://doi.org/10.1016/j.compedu.2011.11.010

Reid, N., \& Yang, M. J. (2002). The solving of problems in chemistry: The more open-ended problems. Research in Science \& Technological Education, 20(1), 83-98. https://doi.org/10.1080/02635140220130948

Resnick, L. (1987). Learning in school and out. Educational Researcher, 16(9), 13-20. https://doi.org/10.2307/1175725

Rooney P. (2012). A theoretical framework for serious game design: Exploring pedagogy, play and fidelity and their implications for the design process. International Journal of Game-Based Learning (IJGBL), 2(4), 41-60. https://doi.org/10.4018/ijgbl.2012100103 
Sabourin, J. L., \& Lester, J. C. (2014). Affect and Engagement in Game-Based Learning Environments. IEEE Transactions on Affective Computing, 5(1), 45-56. https://doi.org/10.1109/T-AFFC.2013.27

Savery, J. R. (2006). Overview of Problem-based Learning: Definitions and Distinctions. Interdisciplinary Journal of Problem-Based Learning, 1(1). 9-20. https://doi.org/10.7771/1541-5015.1002

Smetana, L. K., \& Bell, R. L. (2012). Computer Simulations to Support Science Instruction and Learning: A critical review of the literature. International Journal of Science Education, 34(9), 1337-1370. https://doi.org/10.1080/09500693.2011.605182

Spires, H. A., Hervey, L. G., Morris, G., \& Stelpflug, C. (2012). Energizing Project-Based Inquiry: Middle-Grade Students Read, Write, and Create Videos. Journal of Adolescent \& Adult Literacy, 55(6), 483-493. https://doi.org/10.1002/jaal.00058

Spronken-Smith, R., Angelo, T., Matthews, H., O’Steen, B., \& Robertson, J. (2007). How Effective is Inquiry-Based Learning in Linking Teaching and Research? Paper prepared for an International Colloquium on International Policies and Practices for Academic Enquiry, Marwell, Wichester, UK, April 19-21. http://portal-live.solent.ac.uk/university/rtconference/colloquium_papers.aspx

Srisawasdi, N. (2018). Transforming Chemistry Class with Technology-Enhanced Active Inquiry Learning for the Digital Native Generation. In C. Cox \& W. E. Schatzberg (Eds), International Perspectives on Chemistry Education Research and Practice (pp 221-233). Washington, DC: American Chemical Society. https://doi.org/10.1021/bk-2018-1293.ch014

Srisawasdi, N., \& Panjaburee, P. (2015). Exploring effectiveness of simulation-based inquiry learning in science with integration of formative assessment. Journal of Computers in Education, 2, 323-352. https://doi.org/10.1007/s40692-015-0037-y

Srisawasdi, N., \& Panjaburee, P. (2018). Implementation of Game-transformed Inquiry-based Learning to Promote the Understanding of and Motivation to Learn Chemistry. Journal of Science Education and Technology, 28(2), 152-164. https://doi.org/10.1007/s10956-018-9754-0

Tan, P. H., Ling, S. W., \& Ting, C. Y. (2007). Adaptive digital game based learning framework. Proceedings of the 2nd International Conference on Digital Interactive Multimedia in Entertainment and Arts, 142-146. https://doi.org/10.1145/1306813.1306844

Trautmann, N., MaKinster, J., \& Avery, L. (2004). What makes inquiry so hard? (and why is it worth it?). In J. Staver, D. Zandvliet, J. Tillotson, C. W. Anderson, F. Crawley (Eds.), Proceedings of the National Association for Research in Science 2004 Annual Meeting. National Association for Research on Science Teaching.

Tsai, C-Y., \& Chai, C. S. (2012). The "third"-order barrier for technology-integration instruction: Implications for teacher education. Australasian Journal of Educational Technology, 28(Special issue, 6), 1057-1060. https://doi.org/10.14742/ajet.810 


\section{Macrothink}

Journal of Studies in Education

ISSN 2162-6952

2021, Vol. 11, No. 3

Ulus, B., \& Oner, D. (2020). Fostering Middle School Students' Knowledge Integration Using the Web-Based Inquiry Science Environment (WISE). Journal of Science Education and Technology, 29(2), 242-256. https://doi.org/10.1007/s10956-019-09809-4

Urhahne, D., Schanze, S., Bell, Mansfield, T., \& Holmes, J. (2010). Role of the Teacher in Computer-supported Collaborative Inquiry Learning. International Journal of Science Education, 32(2), 221-243. https://doi.org/10.1080/09500690802516967

Uribe P., Jiménez A., Araya R., Lämsä J., Hämäläinen R., \& Viiri J. (2020). Automatic Content Analysis of Computer-Supported Collaborative Inquiry-Based Learning Using Deep Networks and Attention Mechanisms. In P. Vittorini, T. Di Mascio, L. Tarantino, M. Temperini, R. Gennari \& F. De la Prieta (Eds.), Methodologies and Intelligent Systems for Technology Enhanced Learning, 10th International Conference (pp. 95-105). Springer, Cham. https://doi.org/10.1007/978-3-030-52538-5_11

Vygotsky, L. S. (1978). Mind in Society: the development of higher mental processes. Harvard University Press.

Wen, C-T., Liu, C-C., Chang, H-Y., Chang, C-J., Chang, M-H., Chiang, S-H., Yang, C-W., \& Wang, F-K. (2020). Students' guided inquiry with simulation and its relation to school science achievement and scientific literacy. Computers \& Education, 149, https://doi.org/10.1016/j.compedu.2020.103830

Wohlin, C. (2014). Guidelines for snowballing in systematic literature studies and a replication in software engineering. Proceedings of the 18th International Conference on Evaluation and Assessment in Software Engineering - EASE '14, 38, 1-10. https://doi.org/10.1145/2601248.2601268

Xu, G., \& Xu, X. (2011). Qualitative research of web-based collaborative inquiry learning in higher education. Proceddings of the International Conference on Electrical and Control Engineering, 6710-6714. https://doi.org/10.1109/ICECENG.2011.6056916

Zion, M., \& Mendelovici, R. (2012). Moving from structured to open inquiry: Challenges and limits. Science Education International, 23(4), 383-399.

\section{Copyrights}

Copyright for this article is retained by the author(s), with first publication rights granted to the journal.

This is an open-access article distributed under the terms and conditions of the Creative Commons Attribution license (http://creativecommons.org/licenses/by/4.0/) 